\title{
Mirosław Wincenciak
}

University of Bialystok

\section{SELECTED PROBLEMS OF ENACTING AND INTERPRETATION OF LOCAL LAW AT THE LEVEL OF LOCAL SELF-GOVERNMENT IN POLAND}

\begin{abstract}
This article presents crucial problems of enacting and interpretation of local law. According to the Constitution acts of local law are the source of universally binding law in the territory of the organ issuing such enactments. Enacting of local law by the local self-government is the exercise of its lawmaking function, derived from statutory authorization. Law-making of the local self-government does not have an autonomous character in regard to legal acts. Enacting of local law by local self-government is its duty. The interpretation of the law enacted by the local self-government has its own specifics. Law which is legislated in such way is likely to be corresponding with the expectations of the local community.
\end{abstract}

\section{Introduction}

Constant changes of law, inconsistency of legal regulations and defective legislation techniques are the main challenges for the recipients of law. Above mentioned challenges concern mostly administrative law, which is especially prone to changes. (Kijowski, 2012). Therefore organs that enact and interpret local law play especially important role, in order for the law, which is closest to the citizen, to be comprehensible and clear. Interpretation of law is the consequent process against enactment of law. We can state that problems of interpretation of law can be derived in large part from defective legislation. The aim of this article is to present crucial problems of enacting and interpretation of local law.

\section{Comprehension of local law}

According to the Polish Constitution (Konstytucja Rzeczypospolitej Polskiej z 2 kwietnia 1997 Dz. U. z 1997 Nr 78, poz. 483), organs of local 


\section{Mirostaw Wincenciak}

government and territorial organs of government administration can enact acts of local law on the basis and within the boundaries of empowerment contained in the act. Acts of local law are the source of universally binding law in the territory of the organ issuing such enactments (art. 87 and art. 97 of Polish Constitution Dz. U. z 1997 Nr 78, poz. 483).

The concept of universally binding rules applies to those that have the following attributes:

- are addressed at and bind certain general categories of entities, regardless of the legal and organizational ties connecting them with issuer of enactment,

- clarify the rules for the behavior of certain categories of entities - define the rights and responsibilities,

- are repetitive in the sense, that they are used repeatedly for entities that meet the conditions stated in the rule,

- the state guarantees operation of the universally binding rules with sanction. (Dąbek, 2004, p. 58).

Therefore enactments of local law are law for everyone, who is placed within the situation specified by the act. (Ochendowski, 1991, p. 24). Territorial scope of application of local laws may not overlap closely with the area of operation of the given local self-government unit. They can be enacted for smaller areas, components of the given unit of local self-government. In art. 89 par. 1 of the Act on Voivodeship Self-government (ustawa z dnia 5 czerwca 1998 r. o samorządzie województwa Dz. U. z 2013, poz. 596 j.t.) legislator has specifically stated that the voivodeship council enacts the legal enactments applicable in the voivodeship or part thereof. On the other hand in art. 41 of the Act on District Self-government (ustawa z dnia 5 czerwca 1998 r. o samorządzie powiatowym (Dz. U. z 2013, poz. 595 j.t.)), this principle was explicitly expressed in relation to acts of ordinal character district organs can enact the rules in the area of the district, bigger than the area of one borough.

In the Act on Borough Self-government (ustawa z dnia 8 marca $1990 \mathrm{r}$. o samorządzie gminnym (Dz. U. z 2013, poz. 594 j.t.)), the principle is not expressed, it is assumed, however, that the enactments of local law enacted on this level of local self-government can cover an area smaller than the whole borough. In practice, the act of local law enacted by the borough council, which covers the area usually smaller than the whole borough, is local plan of spatial development, enacted on the basis of the procedure provided in the act on spatial planning and development.

One of the conditions of legality of the basic act is the issue of the act, on the basis of explicit statutory authorization, within the boundaries outlined 
in the authorization. Authorization to issue sub-act cannot be presumed, and the possible inaccuracy of authorization to issue such an act should be regarded as lack of legislative permission, as according to the rules of interpretation, the presumption of competence of the organ is not acceptable. (Wyrok Trybunału Konstytucyjnego z dnia 4 listopada 1997, U 3/97).

Sub-act cannot be contrary to the legal act on the basics of which the authorization to issue sub-act was given, to other legal acts, and the Polish Constitution with other universally binding legal acts. Any regulation of procedure in sub-act must be consistent with the provisions of the legal act. Moreover, the area of human rights and freedoms which, in accordance with the Constitution, belongs to a statutory matter, cannot be regulated by the sub-act. (Dąbek, 2004, p. 59).

Normative character of an act of local law lies in the fact, that it contains directive statements outlying the recipients specific behavior, that is, determining interdictions, orders, rights. To acknowledge that a particular act is normative, it is sufficient to establish that at least one statement contained within the act is of a directive character. For example, not all of the statements contained in the local plan of spatial development are of a directive character.

The essence of the local development plan is that it contains evaluative statements, postulates, but also directive statements - indicating orders or interdictions regarding certain development of the given area. General nature of the norm is that it determines the recipient, indicating his attribute or attributes, or by using the name of the type or general name of the recipient. The abstract nature of the norm signifies that it applies to repetitive behaviors (occurrences) of a particular type. The attribute that distinguishes the normative general act from the individual act (for example: administrative decision) is the method of regulation of the legal relation between the individual and organ. The general normative act contains a legal norm regulating specific social relation of the given sort, that may be created between the organ and the indeterminate category of entities that are in a situation regulated by this norm. However, individual act is directed to a specific recipient or specific recipients and determines their rights and responsibilities.

Enactment of local law differs from the normative act of the internal management considering the fact, that the first resolves, in a commanding manner the rights, and responsibilities of entities not bound by the relation of subordination to organs of local self-government community, while the second defines the duties and responsibilities of individuals and units remaining in relation of organizational or official subordination to each other. 


\section{Mirostaw Wincenciak}

Normative act of internal management is binding only within a specific organizational system. (wyrok Naczelnego Sądu Administracyjnego z dnia 30 sierpnia 2000, I SA 721/00). This means that not every ruling of the legislative organ of the local self-government unit carries the attribute of the enactment of local law.

The norms specified in the enactments of the local law may be the ground, or one of many grounds for the issue of administrative decision (for example, the provisions of the decision of the borough council, issued on the grounds of art. 40 par. 8 and 9 of the Act on Public Roads, (ustawa z dnia 21 marca 1985 r. o drogach publicznych (Dz. U. z 2007 Nr 19, poz. 115 j.t.)) which sets the fees for occupation of the traffic lane, which is administered by the prefect of the borough, constitute the legal basis for the issue of administrative decision, which allows the occupation of the traffic lane and sets the fee for occupation of the lane; this kind of decision is issued when, for example, some entity wants to place an advertisement within the traffic lane).

Authorization contained in the legal act enabling the issue of an enactment of local law has a higher level of liberalism compared with the authorization to issue a regulation. According to the Constitution (art. 94 par. 1 - Dz. U. z 1997 Nr 78, poz. 483), the statutory authority to issue a regulation by the central organ of public administration must be specific, define the scope of matters to be regulated by the regulation, as well as provide guidelines concerning the content of the regulation. With regard to the authorization to issue enactments of local law, according to constitutional regulation, contents of enactments of local law do not require guidelines (Bogusz, 2008, p. 14-15).

\section{Grounds for enacting law at the local level}

Among the reasons for delegating the competence of enacting universally binding law to local authorities are the following circumstances:

- the necessity to take into account the specifics of the local conditions, which can be better considered by the local self-government organs;

- ensuring the fast legislative action in the event of emergencies requiring immediate response at the local level,

- the necessity to consider the specific issues in the legal regulation - the task is met by the local enactments as sub-acts,

- delegation of legislative authority to local organs is justified by the rationality of the division of administrative tasks, 
- in some cases, local law (ordinal rules) can fill gaps in the legal system,

- law enacted by the local self-government is constituted with the help of the public (local community representatives), which should increase the acceptance of the law, resulting in it being more effective,

- certain tasks are carried out by the local self-government better and more effectively than by the central administration. (Dąbek, 2004, p. 85-87).

Enacting of local law by the local self-government is the exercise of its law-making function, derived from statutory authorization. Law-making of the local self-government does not have an autonomous character in regard to legal acts. Enacting of local law by local self-government is its duty. That may be an unconditional obligation, when the statutory authorization imposes obligation to enact an act of local law regulating certain categories of social relationships (i.e., the act on local taxes and fees - the borough council will issue a resolution on property tax rates), and also have a form of authorization for optional enacting of an act of local law (for example, under art. 15 par. 7 of Act on Transportation, (ustawa z dnia 6 września $2001 \mathrm{r}$. o transporcie drogowym (Dz. U. z 2012 r. poz. 1265 j.t.)) the borough council may introduce the requirement for the use of supplementary indications and additional technical equipment for the taxi cabs).

\section{Types of local law enactments}

Enactments of local law can be divided into acts bearing different character: executive, ordinal and systemic-organizational. Executive enactments are issued on the basis of specific statutory authorization within the limits specified by the act. System norms, indicating categories of tasks belonging to a certain level of local self-government, do not provide sufficient grounds for the issue of enactments. Resolutions issued on the basis of specific authorization regulate different categories of social relations - according to statutory regulation and authority contained therein. These enactments cannot outstretch the object of regulation beyond the scope of statutory authorization, they also cannot modify or extend the interdicts contained within legal acts.

Enactments of systemic-organizational character include the statutes of local self-government units, auxiliary units of boroughs, municipal associations, as well as acts regulating the rules of local government units' property management. Legitimacy to enact statutes of local self-government units results directly from the art. 169 par. 4 of the Polish Constitution. 


\section{Mirostaw Wincenciak}

(Dz. U. z 1997 Nr 78, poz. 483). Statute does not constitute "sub-act" law in the same meaning as for the other acts of local law. (Dąbek, 2005, p. 423-424). The mere possibility of constitution of the statute of the local self-government unit is independent of the common legislation, since the constitution of an act of local law determining the internal organization of local self-government unit does not require a statutory basis in the system regulations. Systemic legal acts, on the other hand, do limit the content of the abovementioned acts. (Szewczyk, 2001, p. 710). In the area of statute regulations local self-government is left with some freedom. For example, in accordance with art 23 par. 2 Act on Borough Self-government (Dz. U. z 2013, poz. 594 j.t.) councilors can create councilors' clubs working on the principles described in the statute of the borough. The subject of statute regulation may be the issues concerning the determination of the minimum composition of the councilors' club and the detailed rules for its operation. (wyrok Naczelnego Sądu Administracyjnego z dnia 8 lutego 2005, OSK 1122/04, wyrok Naczelnego Sądu Administracyjnego z dnia 23 maja 2005, OSK 1616/04)).

The third group of local law enactments - are the so-called ordinal rules, which are issued at the level of borough self-government, as well as the district self-government. At the level of voivodeship only organs of government administration are authorized to issue ordinal rules. Authorization for enacting results from the general authorization contained in the systemic legal acts. Systemic legal acts point to three conditions required to enact legal ordinal rule:

- existing threat to the goods specified in the systemic legal acts,

- lack of regulations for the protection of the goods,

- indispensability of enacting of the ordinal rules to remove the threat to the goods specified in the systemic legal acts.

Art. 40, par. 3 Act on Borough Self-government (Dz. U. z 2013, poz. 594 j.t.) lists life or health of citizens and maintaining public order, peace and safety as protected goods. In art. 41 par. 1 Act on District Selfgovernment (Dz. U. z 2013, poz. 595 j.t.) besides the goods specified in Act on Borough Self-government property of citizens, and environmental protection has been mentioned.

Ordinal rule enacted by the local self-government must fill so-called objective loophole (Dobosz, 2004, p. 275), meaning the lack of regulation of specific situations (occurrences), and should not change the legal regulations already in force. Organ enacting the ordinal rules must therefore determine whether a particular type of behavior is not already regulated, and secondly if the lack of regulation is not intended by the legislature. 
Selected Problems of Enacting and Interpretation of Local Law...

\section{Legislative omission}

The subject of enacting of local law is related to the issue of legislative omission of local self-government units. Omission occurs when: organ of the local self-government does not issue a resolution despite statutory authorization or does not re-issue the regulation as a result of its annulment by the supervisor or administrative court; when the given act of local law does not contain all the elements of regulation required by legal act, or when issued resolution has not been publicized, and its publication is required for it to enter into force. (Stahl, 2006, p. 5). Among the examples of legislative omission we can point out: lack of regulation of the issues concerning the retirement of auxiliary units in the statute of the borough, or not issuing a resolution on liquidation or change of the form of the financial management of independent public health office, due to a negative financial result by that office - art. 60 par. 1 and 3 of the act of 30 August 1991 on health care (ustawa z dnia 30 sierpnia $1991 \mathrm{r}$. o zakładach opieki zdrowotnej (Dz. U. z $1991 \mathrm{Nr}$ 91, poz. 408 ze zm.)).

Act - law on Proceedings Before Administrative Courts (ustawa z dnia 30 sierpnia $2002 \mathrm{r}$. - Prawo o postępowaniu przed sądami administracyjnymi (Dz. U. 2012, poz. 270)) does not provide the possibility to sue for inactivity resulting in the omission to issue the resolution by the local self-government organs - article $3 \S 2$ Act - Law on Proceedings Before Administrative Courts (Dz. U. 2012, poz. 270).

\section{Other problems of interpretation of the law}

It is a truism to say, that the rules of interpretation of local law are similar to the rules of interpretation of acts of another level. However, the characteristics of this law, such as the binding force in the particular area, or executive nature of most normative acts also point to the specificity of the interpretation of the law. Firstly, it boils down to the fact that the subject which enacts and interprets are the organs of local self-government; secondly the possible elimination of any such provisions due to their non-compliance with other norms standing higher in the hierarchy of sources of law takes place under different rules. In the case of other universally binding laws, their compliance or non-compliance with the Constitution or other legal acts is subject to evaluation of the Constitutional Tribunal. Regarding the regulations issued on the basis of the legal act, all public courts are constitutional in a way, because they can ignore the provision of the regulation 


\section{Mirostaw Wincenciak}

inconsistent with legal act or the Constitution. However, the evaluation of legality of local law is substantially made on a different level, as it is performed by the supervising organs and administrative courts. The court's decision on the legality of the act of local law is also an interpretation of this act, as a court ruling is a consequence of earlier interpretation of the act. Administrative court evaluating the legality of an act of local law should make pro-constitutional and pro-legal interpretation. However, the interpretation procedure must comply with the assumption that understanding of a particular expression accepted as consistent with the Constitution or the legal act lies within the so-called possible linguistic meaning. (Spyra, 2006 , p. 39). The boundary of pro-constitutional and pro-legal interpretation is therefore admissible linguistic meaning of interpreted expression or provision.

Administrative organs, as well as administrative courts repeatedly have doubts as to the legal nature of many categories of resolutions of organs of local self-government, namely whether the enactments bear the character of the local laws or not. It is important if only because of the obligation to publish a local enactment in the voivodeship official journal. In jurisdiction this problem is visible on the background of the resolutions on the establishment of the budgetary unit. We can find the rulings of the administrative courts where it is assumed that the resolution on establishment of a budgetary unit is an act of local law - ruling of Provincial Administrative Court in Wrocław (wyrok Wojewódzkiego Sądu Administracyjnego we Wrocławiu, z dnia 5 czerwca 2008, III SA/Wr 125/08; wyrok Wojewódzkiego Sądu Administracyjnego we Wrocławiu z dnia 6 lutego 2005, IV SA/Wr 830/04), and in other rulings they are denied normative character. (wyrok Naczelnego Sądu Administracyjnego z dnia 12 października 2005, II OSK 134/05). According to M. Stahl (2006), "Supreme Control Chamber study shows that local self-government organs have difficulty in classifying many acts enacted by themselves as local laws or other acts". The task is not made easier by the legislator, as he inconsistently uses certain terms. I mean the indications in some legal acts pointing to certain resolutions of organs of local self-government being local law. On the other hand, in relation to other acts which, according to judicature and scientific papers are acts of local law, the legislator is mute. This would suggest that only the resolutions named by the legislator as a local law bear the character, but in reality it is not the case. Undoubtedly, the Rules of legislative drafting play organizing role in both the regulation process and in the process of interpretation. They are legislative guidelines for the creation of laws that should be taken into account by law-making entities. In 
the literature, it is pointed out that lifting the Rules of legislative drafting to the rank of regulation expresses the belief of the legislator, that they fulfill an important role in achieving a good state but it does not change their character; according to their nature they remained the rules of constructing correct normative acts and reliably making amendments, but not the rules of construction of "important" normative acts. (Wronkowska, 2004, p. 20). The Rules of legislative drafting do not express typical legal norms, but technical directives (purpose). (Wronkowska, 1990, p. 7). Technical Directive (purpose) is an expression similar to the norm of conduct, which sets out, in a conditional manner, the obligation of particular recipients' behavior, which can be reduced to linguistic pattern: "If you want to achieve objective C, you should behave in a manner S". (Bator, 2006, p. 78).

The literature and jurisdiction repeatedly pointed to the importance of justification of a normative act. According to art. 143 in connection with art. 131 par. 1 of the Rules of legislative drafting - (rozporządzenie Rady Ministrów 20 czerwca 2002 r. w sprawie zasad techniki prawodawczej (Dz. U. z $2002 \mathrm{Nr}$ 100, poz. 908)), legal enactments of local law shall include a justification. In judicature we can meet different views on the importance of the possible lack of justification of a normative act. There is a firm position that the lack of justification of the draft of resolution of local self-government unit justifies the invalidity of such an act. There is also a different view that the Rules of legislative drafting are a set of directives addressed at the legislator, showing how to properly express legal norms in legal acts and how to group them in normative acts. However, they do not serve the assessment of the validity of the standing law. (Wyrok Naczelnego Sacdu Administracyjnego z dnia 5 maja 2011, I OSK 1059/10).

In summary the interpretation of the law enacted by the local selfgovernment has its own specifics. This is due to the following circumstances: high level of details in regulation resulting from the executive character of the local law, decentralization of law-making process - authorization of legislative organs of units of local self-government to enact, which means that the number of entities enacting the law is expressed in thousands. Such a large number of law-making entities must lead to noticeable differences in the regulations, what is also an advantage of local law. Law which is legislated in such way is likely to be corresponding with the expectations of the local community. On the other hand, it may be on the wrong legislative level. Therefore, the Rules of legislative drafting undoubtedly have an important role to fulfill - they should be treated as a standard of conduct for local legislators. 


\section{Mirosław Wincenciak}

\section{R E F E R E N C E S}

Bator, A. (2006). In Andrzej Bator et al., Wprowadzenie do nauk prawnych. Leksykon tematyczny (p. 78). Warszawa: LexisNexis Polska.

Bogusz, M. (2008). Wadliwość aktu prawa miejscowego. Studium z zakresu nauki prawa administracyjnego. Gdańsk: Wydawnictwo Uniwersytetu Gdańskiego, $14-15$.

Dąbek, D. (2004). Prawo miejscowe samorzadu terytorialnego. Bydgoszcz - Kraków: Oficyna Wydawnicza Branta, 58.

Dąbek, D. (2005). In P. Chmielnicki (Ed.), Komentarz do ustawy o samorzadzie województwa (p. 423-424). Warszawa: Lexis Nexis Polska.

Dobosz, P. (2004). In P. Chmielnicki (Ed.), Komentarz do ustawy o samorzadzie gminnym (p. 275). Warszawa: LexisNexis Polska.

Kijowski, D., R. et al. (2012). (Eds.). Kryzys prawa administracyjnego?, volume 4: Wykkadnia i stosowanie prawa administracyjnego. Warszawa: Wolters Kluwer Polska.

Ochendowski, E. (1991). Prawotwórcza funkcja gminy. Ruch Prawniczy Ekonomiczny i Socjologiczny, 2, 24.

Konstytucja Rzeczypospolitej Polskiej z 2 kwietnia 1997 (Dz. U. z 1997 Nr 78, poz. 483$)$.

Spyra, T. (2006). Granice wykładni prawa. Kraków: Kantor Wydawniczy Zakamycze, 39 .

Stahl, M. (2006). Legislative omission of the units of local self-government. Chosen aspects. Administracja: teoria, praktyka, dydaktyka, 1, 5 .

Szewczyk, M. (2001). Miejsce aktów określających ustrój jednostek samorządu terytorialnego w strukturze źródeł prawa administracyjnego. In I. SkrzydłoNiżnik et al. (Eds.), Instytucje wspótczesnego prawa administracyjnego. Ksiega jubileuszowa profesora zw. dra hab. Józefa Filipka (p. 710). Kraków: Wydawnictwo Uniwersytetu Jagiellońskiego.

Rozporządzenie Rady Ministrów 20 czerwca 2002 r. w sprawie zasad techniki prawodawczej (Dz. U. z $2002 \mathrm{Nr}$ 100, poz. 908).

Ustawa z dnia 21 marca 1985 r. o drogach publicznych (Dz. U. z 2007 Nr 19, poz. 115 j.t.).

Ustawa z dnia 8 marca 1990 r. o samorządzie gminnym (Dz. U. z 2013, poz. 594 j.t.).

Ustawa z dnia 30 sierpnia 1991 r. o zakładach opieki zdrowotnej (Dz. U. z 1991 Nr 91, poz. 408 ze zm.).

Ustawa z dnia 5 czerwca 1998 r. o samorządzie powiatowym (Dz. U. z 2013, poz. 595 j.t.).

Ustawa z dnia 5 czerwca 1998 r. o samorządzie województwa (Dz. U. z 2013, poz. 596 j.t.).

Ustawa z dnia 6 września 2001 r. o transporcie drogowym (Dz. U. z 2012 r. poz. 1265 j.t.). 
Ustawa z dnia 30 sierpnia $2002 \mathrm{r}$. Prawo o postępowaniu przed sądami administracyjnymi (Dz. U. 2012, poz. 270).

Wronkowska, S. (1990). Technika legislacyjna. Ruch Prawniczy Ekonomiczny i Socjologiczny, 1, 7 .

Wronkowska, S. (2004). In S. Wronkowska, M. Zieliński (Eds.), Komentarz do zasad techniki prawodawczej (p. 20). Warszawa: Wydawnictwo Sejmowe.

Wyrok Naczelnego Sądu Administracyjnego z dnia 30 sierpnia 2000, I SA 721/00, from: http://www.orzeczenia.nsa.gov.pl, retrieved November 29, 2012.

Wyrok Naczelnego Sądu Administracyjnego z dnia 8 lutego 2005, OSK 1122/04, from: http://www.orzeczenia.nsa.gov.pl, retrieved November 29, 2012.

Wyrok Naczelnego Sądu Administracyjnego z dnia 23 maja 2005, OSK 1616/04, from: http://www.orzeczenia.nsa.gov.pl, retrieved November 29, 2012.

Wyrok Naczelnego Sądu Administracyjnego w Warszawie z dnia 12 października 2005, II OSK 134/05, ONiWSA 2005, 5, poz. 137.

Wyrok Naczelnego Sądu Administracyjnego z 5 maja 2011, I OSK 1059/10, Lex 990131.

Wyrok Trybunału Konstytucyjnego z 4 listopada 1997, U 3/97, OTK 1997, nr 3-4, poz. 40.

Wyrok Wojewódzkiego Sądu Administracyjnego we Wrocławiu z dnia 6 lutego 2005 r. (IV SA/Wr 830/04), from: http://www.naszawokanda.pl/orzeczenie/ gvcvs/wsa,IV-SA-Wr-830-04,samorzad_terytorialny/, retrieved November 29, 2012.

Wyrok Wojewódzkiego Sądu Administracyjnego we Wrocławiu z dnia 5 czerwca 2008 (III SA/Wr 125/08), from: http://www.orzeczenia.nsa.gov.pl, retrieved November 29, 2012. 